Int. J. Dev. Biol. 59: 357-366 (2015)

doi: $10.1387 / \mathrm{ijdb} .150171 \mathrm{wb}$

\title{
Dual roles of voltage-gated sodium channels in development and cancer
}

\author{
FAHEEMMUDDEEN PATEL and WILLIAM J. BRACKENBURY* \\ Department of Biology, University of York, Heslington, York, UK
}

\begin{abstract}
Voltage-gated $\mathrm{Na}^{+}$channels (VGSCs) are heteromeric protein complexes containing pore-forming $\alpha$ subunits together with non-pore-forming $\beta$ subunits. There are nine $\alpha$ subunits, $\mathrm{Na}_{v} 1.1-\mathrm{Na}_{v} 1.9$, and four $\beta$ subunits, $\beta 1-\beta 4$. The $\beta$ subunits are multifunctional, modulating channel activity, cell surface expression, and are members of the immunoglobulin superfamily of cell adhesion molecules. VGSCs are classically responsible for action potential initiation and conduction in electrically excitable cells, including neurons and muscle cells. In addition, through the $\beta 1$ subunit, VGSCs regulate neurite outgrowth and pathfinding in the developing central nervous system. Reciprocal signalling through $\mathrm{Na}_{\mathrm{v}} \mathrm{1.6}$ and $\beta 1$ collectively regulates $\mathrm{Na}^{+}$current, electrical excitability and neurite outgrowth in cerebellar granule neurons. Thus, $\alpha$ and $\beta$ subunits may have diverse interacting roles dependent on cell/tissue type. VGSCs are also expressed in non-excitable cells, including cells derived from a number of types of cancer. In cancer cells, VGSC $\alpha$ and $\beta$ subunits regulate cellular morphology, migration, invasion and metastasis. VGSC expression associates with poor prognosis in several studies. It is hypothesised that VGSCs are up-regulated in metastatic tumours, favouring an invasive phenotype. Thus, VGSCs may have utility as prognostic markers, and/or as novel therapeutic targets for reducing/preventing metastatic disease burden. VGSCs appear to regulate a number of key cellular processes, both during normal postnatal development of the CNS and during cancer metastasis, by a combination of conducting (i.e. via $\mathrm{Na}^{+}$current) and non-conducting mechanisms.
\end{abstract}

KEY WORDS: cancer, development, migration, metastasis, voltage-gated $\mathrm{Na}^{+}$channel

\section{Introduction}

Voltage-gated $\mathrm{Na}^{+}$channels (VGSCs) are heteromeric membrane protein complexes containing pore-forming $\alpha$ subunits in association with non-pore-forming $\beta$ subunits (Fig. 1) (Catterall, 2000). The $\beta$ subunits regulate channel gating and are also cell adhesion molecules (CAMs) (Brackenbury and Isom, 2011). The classical role of VGSCs is the initiation and conduction of action potentials in electrically excitable cells, e.g. neurons (Hille, 1992). However, VGSCs are also expressed in a number of "non-excitable" cells, including fibroblasts, glia, immune cells, and cancer cells, where their role is less well understood (Brackenbury et al., 2008b). Clearly, in both excitable and non-excitable cells, VGSCs regulate a number of key cellular processes, by a combination of conducting (i.e. via $\mathrm{Na}^{+}$current) and non-conducting mechanisms. The purpose of this article is to provide an up-to-date review of the current evidence suggesting a dual role for VGSCs in regulating cellular migration during central nervous system development and cancer progression.

\section{Structure and function of VGSCs}

The pore-forming $\alpha$ subunit consists of four homologous domains, each with six transmembrane segments. The pore is formed from

\footnotetext{
Abbreviations used in this paper: BACE1, $\beta$-secretase; CAM, cell adhesion molecule; CGN, cerebellar granule neuron; CNS, central nervous system; DI:S3, domain I segment 3; EGF, epidermal growth factor; ERK, extracellular signal-regulated kinase; GEFS+, genetic epilepsy with febrile seizures plus; MEF, mouse embryonic fibroblast; MS, multiple sclerosis; NGF, nerve growth factor; NHE1, $\mathrm{Na}^{+} / \mathrm{H}^{+}$ exchanger 1; PKA, protein kinase A; PNS, peripheral nervous system; RPTP $\beta$, receptor tyrosine phosphatase $\beta$; TLE, temporal lobe epilepsy; VEGF, vascular endothelial growth factor; VGSC, voltage-gated $\mathrm{Na}^{+}$channel; $\mathrm{V}_{\mathrm{m}}$, membrane potential.
}

\footnotetext{
*Address correspondence to: William J. Brackenbury. Department of Biology, University of York, Wentworth Way, Heslington, York YO10 5DD, UK. Tel: +44-1904-328284. Fax: +44-1904-328505. E-mail: william.brackenbury@york.ac.uk -

Web: http://www.york.ac.uk/biology/research/molecular-cellular-medicine/will-brackenbury
}

Accepted: 4 June 2015

ISSN: Online 1696-3547, Print 0214-6282

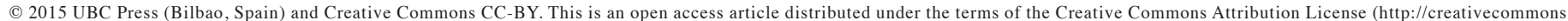

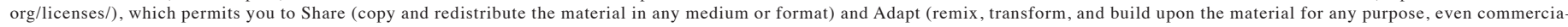

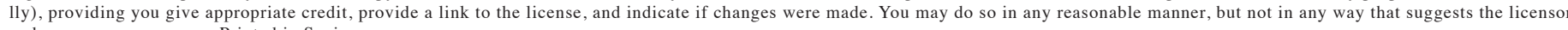
endorses you or your use. Printed in Spain. 
TABLE 1

TISSUE AND CANCER EXPRESSION OF VGSCs

\begin{tabular}{|c|c|c|c|}
\hline Protein & Gene & Tissue location & Cancer type \\
\hline \multicolumn{4}{|c|}{ (A) $\alpha$ subunits (Brackenbury, 2012, Goldin et al., 2000) } \\
\hline $\mathrm{Na}_{v} 1.1$ & SCN1A & CNS, PNS, heart & Ovarian \\
\hline $\mathrm{Na}_{\mathrm{v}} 1.2$ & $S C N 2 A$ & CNS, PNS & Cervical, mesothelioma, ovarian, prostate \\
\hline $\mathrm{Na}_{v} 1.3$ & $S C N 3 A$ & CNS, PNS & Ovarian, prostate, small cell lung cancer \\
\hline $\mathrm{Na}_{\mathrm{v}} 1.4$ & $S C N 4 A$ & Skeletal muscle & Cervical, ovarian, prostate \\
\hline $\mathrm{Na}_{\mathrm{v}} 1.5$ & SCN5A & Uninnervated skeletal muscle, heart, brain & Breast, colon, lymphoma, neuroblastoma, non-small cell lung cancer, ovarian, small cell lung cancer \\
\hline $\mathrm{Na}_{\mathrm{v}} 1.6$ & $S C N 8 A$ & CNS, PNS, heart & Breast, cervical, lymphoma, melanoma, mesothelioma, non-small cell lung cancer, prostate, small cell lung cancer \\
\hline $\mathrm{Na}_{v} 1.7$ & SCN9A & PNS, neuroendocrine cells, sensory neurons & Breast, cervical, lymphoma, mesothelioma, non-small cell lung cancer, ovarian, prostate \\
\hline $\mathrm{Na}_{\mathrm{v}} 1.8$ & SCN10A & sensory neurons & Prostate \\
\hline $\mathrm{Na}_{\mathrm{v}} 1.9$ & SCN11A & sensory neurons & Lymphoma, small-cell lung cancer \\
\hline \multicolumn{4}{|c|}{ (B) $\beta$ subunits (Brackenbury, 2012, Brackenbury and Isom, 2011) } \\
\hline$\beta 1$ & SCN1B & Heart, skeletal muscle, adrenal gland, CNS, glia, PNS & Breast, cervical, non-small cell lung cancer, prostate \\
\hline$\beta 2$ & $S C N 2 B$ & CNS, PNS, heart, glia & Breast, cervical, non-small cell lung cancer, prostate \\
\hline$\beta 3$ & $S C N 3 B$ & CNS, adrenal gland, kidney, PNS & Non-small cell lung cancer, prostate \\
\hline$\beta 4$ & $S C N 4 B$ & Heart, skeletal muscle, CNS, PNS & Breast, cervical, non-small cell lung cancer, prostate \\
\hline
\end{tabular}

the membrane dipping loop between the 5th and 6th transmembrane segments of each domain (Fig. 1) (Catterall, 2000). There are nine $\alpha$ subunits, $\mathrm{Na}_{\mathrm{v}} 1.1-\mathrm{Na}_{\mathrm{v}} 1.9$, encoded by SCN1A-SCN11A(Catterall, 2000). The different $\alpha$ subunits have unique, but often overlapping, tissue-specific expression patterns (Table 1A) (Goldin et al., 2000). There is considerable electrophysiological and pharmacological diversity between $\alpha$ subunits, which may, in part explain their tissue specificity (Catterall, 2000). Alternative splicing of $\alpha$ subunits provides additional functional, developmental, and tissue-specific variability (Diss et al., 2004). Four genes (SCN1B-SCN4B) encode five different $\beta$ subunits, $\beta 1$, and its splice variant $\beta 1 B$, and $\beta 2-4$ (Table 1B) (Brackenbury and Isom, 2011). With the exception of $\beta 1 \mathrm{~B}$, the $\beta$ subunits are type 1 topology transmembrane proteins, with a small intracellular $\mathrm{C}$-terminus, and an extracellular $\mathrm{N}$-terminus containing an immunoglobulin loop (Fig. 2) (Gilchrist et al., 2013, Isom et al., 1992, Namadurai et al., 2014). $\beta 1 \mathrm{~B}$ is a splice variant of $\beta 1$, which, through the retention of exon $3 A$, transcribes an early stop codon and does not contain the transmembrane region of $\beta 1$ (Kazen-Gillespie et al., 2000, Qin et al., 2003). $\beta 1$ and $\beta 3$ are non-covalently linked to $\alpha$ subunits, whereas $\beta 2$ and $\beta 4$ are covalently linked (Isom et al., 1992, Isom et al., 1995, Morgan et al., 2000, Yu et al., 2003).

Classically, the $\beta$ subunits modulate the biophysical properties of the $\alpha$ subunit. For example, $\beta 1$ and $\beta 2$ increase current density,<smiles></smiles>

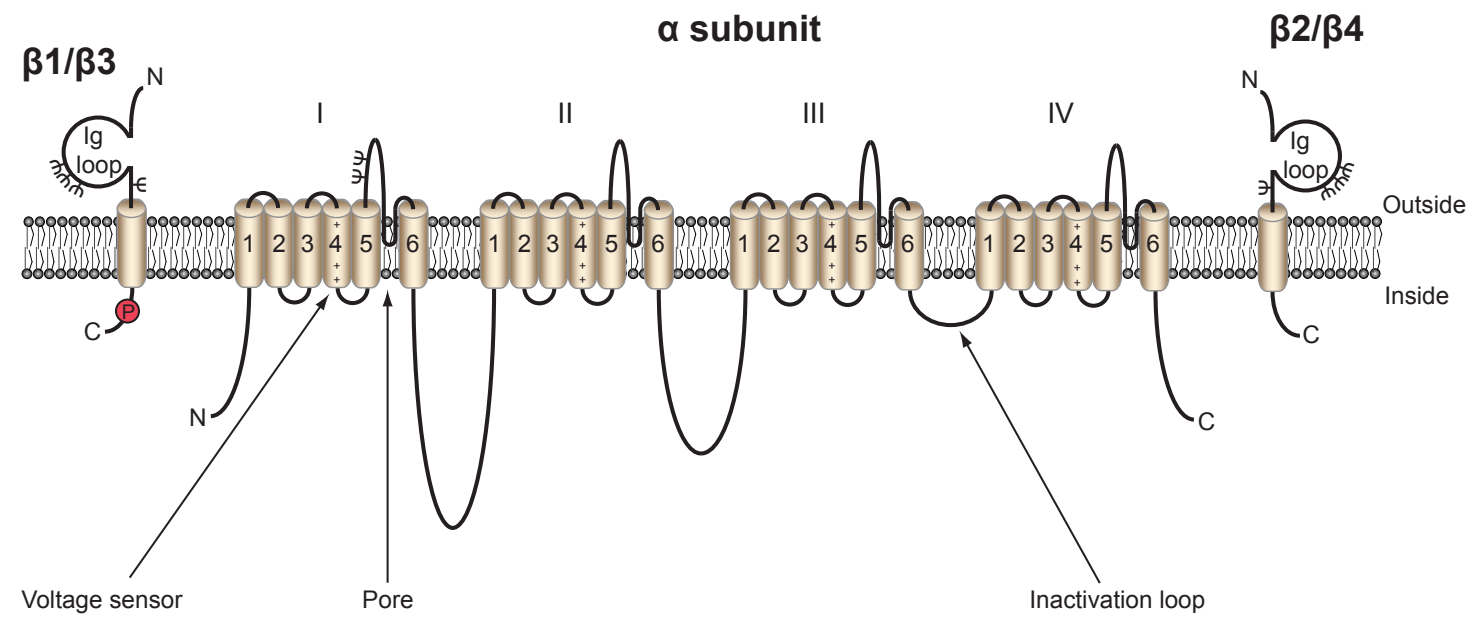

Fig. 1. Topology of VGSCs. VGSCs contain a pore-forming $\alpha$ subunit that has four homologous domains, each containing six transmembrane segments. The voltage sensor is in segment 4 (Catterall, 2000). The $\beta$ subunits contain an extracellular immunoglobulin (lg) loop, transmembrane domain, and an intracellular C-terminal domain, with the exception of $\beta 1 B$, which lacks a transmembrane domain, and is thus a soluble protein (Patino et al., 2011). Red $P$, tyrosine phosphorylation site in $\beta 1$ C-terminus (Malhotra et al., 2004); $\psi$, glycosylation sites. Figure as originally published in Brackenbury WJ and Isom LL (2011) Na+ Channel $\beta$ Subunits: Overachievers of the Ion Channel Family. Front. Pharmacol. 2:53. doi: 10.3389/fphar.2011.00053. 
accelerate inactivation, and hyperpolarize the voltage dependence of inactivation in heterologous cells (Isom et al., 1992, Isom et al., 1995). In contrast, $\beta 3$ depolarizes the voltage dependence of activation and inactivation of $\mathrm{Na}_{\mathrm{v}} 1.3$ in HEK-293 cells (Cusdin et al., 2010), and increases $\mathrm{Na}^{+}$current density by enhancing trafficking of $\mathrm{Na}_{v} 1.5$ to the plasma membrane (Ishikawa et al., 2013). $\beta 4$ hyperpolarizes the voltage-dependence of activation of $\mathrm{Na}_{v} 1.2$ in tsA-201 cells (Qu et al., 2001, Yu et al., 2003). In addition, the intracellular domain of $\beta 4$ has been proposed to act as an openchannel blocker in cerebellar Purkinje neurons (Grieco et al., 2005). However, there have been inconsistent reports on the type and magnitude of alteration of the $\mathrm{Na}^{+}$current by individual $\beta$ subunits, which may be dependent on the cell line/type used (Meadows and Isom, 2005, Moran et al., 2003). This variability may be due to differences in the endogenous levels of $\alpha$ subunits and $\beta$ subunits and different glycosylation states. For example, $\beta 1$ and $\beta 3$ have recently been shown to alter glycosylation of $\mathrm{Na}_{v} 1.7$ in HEK293 cells (Laedermann et al., 2013). Interestingly, the $\beta$ subunits may also regulate other classes of ion channels. For example, $\beta 1$ regulates A-type $\mathrm{K}^{+}$currents in isolated cortical neurons (Marionneau et al., 2012), and modifies $\mathrm{K}_{\mathrm{v}} 4.3$ gating in cardiomyocytes (Deschenes et al., 2008, Deschenes and Tomaselli, 2002). $\beta 1$ has also been shown to modulate the biophysical properties of $\mathrm{K}_{\mathrm{v}} 1.1, \mathrm{~K}_{\mathrm{v}} 1.2$, $\mathrm{K}_{\mathrm{v}} 1.3, \mathrm{~K}_{\mathrm{v}} 1.6$, and $\mathrm{K}_{\mathrm{v}} 7.2$ (Nguyen et al., 2012).

In addition to regulating $\mathrm{Na}^{+} / \mathrm{K}^{+}$current, the presence of the immunoglobulin loop means that the $\beta$ subunits are also CAMs. $\beta 1$ can interact both homophilically and heterophilically with a number of extracellular proteins and other CAMs, including $\beta 2$, contactin, neurofascin-186, NrCAM, N-cadherin, and tenascin-R (Fig. 2) (Kazarinova-Noyes et al., 2001, Malhotra et al., 2000, McEwen and Isom, 2004, Ratcliffe et al., 2001, Xiao et al., 1999). $\beta 2$ also interacts with tenascin- $C$ and tenascin- $R$ (Srinivasan et al., 1998). In Chinese hamster lung cells, phosphorylation of the intracellular $Y 181$ residue on $\beta 1$ abolishes recruitment of ankyrin and ankyrin ${ }_{B}$ (Malhotra et al., 2002). Further, phosphorylation of Y181 regulates subcellular localization of $\beta 1$ to the intercalated disks in cardiomyocytes (Malhotra etal., 2004). $\beta 3$ shows significant homology to $\beta 1$. However, when expressed in Drosophila S2 cells, $\beta 3$ does not participate in trans-homophilic adhesion, nor does it interact with $\beta 1$ or contactin in Chinese hamster lung cells, but does interact with neurofascin-186 (McEwen et al., 2009, McEwen and Isom, 2004). In contrast, a recent study has shown that in HEK-293 cells, the immunoglobulin domain of $\beta 3$ can indeed participate in trans-homophilic binding, and can interact heterophilically with $\beta 1$ (Yereddi et al., 2013). Clearly, further work is required to resolve these conflicting observations, and $\beta 3$-mediated adhesive interactions may be dependent on species/cell type.

\section{VGSCs in Central Nervous System development}

Electrical activity is required for axonal and dendritic development and synaptogenesis in the retinogeniculate pathway and visual cortex (Casagrande and Condo, 1988, Riccio and Matthews, 1985). Similarly, deletion of $\mathrm{Na}_{v} 1.1, \mathrm{Na}_{v} 1.2$, or $\mathrm{Na}_{v} 1.6$ in mice results in central nervous system (CNS) defects and premature lethality (Harris and Pollard, 1986, Planells-Cases et al., 2000, Yu et al., 2006). Thus, $\alpha$ subunit expression and activity appear to be critical for normal CNS development. Fine-tuning of electrical activity via VGSC $\alpha$ subunit expression is tightly regulated during development. For example, $\mathrm{Na}_{\mathrm{v}} 1.3$ is expressed during foetal development and is replaced by $\mathrm{Na}_{v} 1.1, \mathrm{Na}_{v} 1.2$, and $\mathrm{Na}_{v} 1.6$ postnatally (Beckh et al., 1989, Schaller and Caldwell, 2000). Later in postnatal devel-
Fig. 2. Functional map of $\boldsymbol{\beta} 1$. The extracellular immunoglobulin loop interacts with other cell adhesion molecules and extracellular matrix proteins (Kazarinova-Noyes et al., 2001, Malhotra et al., 2000, McEwen and Isom, 2004, Ratcliffe et al., 2001, Xiao et al., 1999). A number of mutations at the indicated sites in and adjacent to the immunoglobulin loop have been identified as responsible for causing temporal lobe epilepsy (TLE) and genetic epilepsy with febrile seizures plus (GEFS+) (Patino and Isom, 2010). Other sites indicated: alternative splice site, putative palmitoylation site, secretase cleavage sites, glycosylation sites $(\psi)$, sites for interaction with ankyrin, receptor tyrosine phosphatase $\beta$ (RPTP $\beta$ ), and fyn kinase (Bracken-

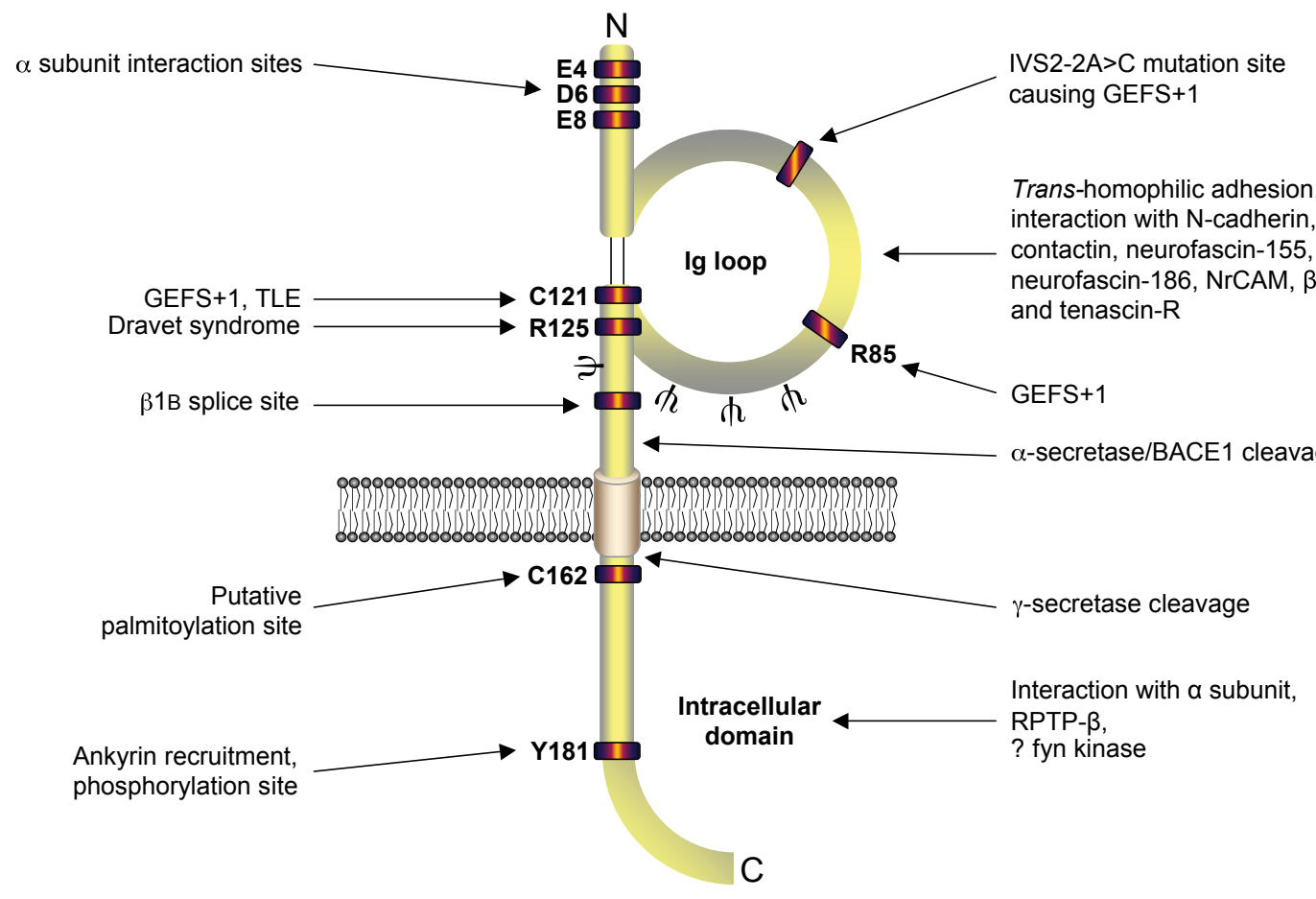

bury et al., 2008a, Malhotra et al., 2002, Malhotra et al., 2004, Patino et al., 2011, Wong et al., 2005). Figure as originally published in Brackenbury WJ and Isom LL (2011) Na+ Channel $\beta$ Subunits: Overachievers of the Ion Channel Family. Front. Pharmacol. 2:53. doi: 10.3389/fphar.2011.00053. 
opment, $\mathrm{Na}_{v} 1.6$ replaces $\mathrm{Na}_{v} 1.2$ at the axon initial segment, and nodes of Ranvier following myelination (Boiko et al., 2001, Boiko et al., 2003, Kaplan et al., 2001). Interestingly however, $\alpha$ subunits may also play a non-conducting role (independent of $\mathrm{Na}^{+}$current) in regulating tissue development. For example, $\mathrm{Na}_{v} 1.5$ expression is required for normal heart development in zebrafish (Chopra et al., 2010). Further developmental regulation of VGSCs is achieved by alternative splicing. Alternative splicing in domain I segment 3 (DI:S3) occurs in a number of the $\alpha$ subunits, and is developmentally regulated for $\mathrm{Na}_{v} 1.2, \mathrm{Na}_{v} 1.3$ and $\mathrm{Na}_{v} 1.5$ (Diss et al., 2004).

$\beta$ subunit expression is also developmentally regulated. During CNS development, the SCN1B splice variant $\beta 1 B$ is predominantly expressed embryonically (Kazen-Gillespie et al., 2000, Patino et al., 2011). In contrast, $\beta 1$ expression increases from birth, peaking at postnatal day 14 in mice (Kazen-Gillespie et al., 2000). Finally, the developmentally regulated expression profile of VGSCs is disrupted in CNS diseases. For example, in multiple sclerosis (MS), $\mathrm{Na}_{v} 1.2, \mathrm{Na}_{v} 1.6$ and $\mathrm{Na}_{v} 1.8$ are up-regulated in CNS neurons in response to demyelination (Black et al., 2000, Craner et al., 2004).

A

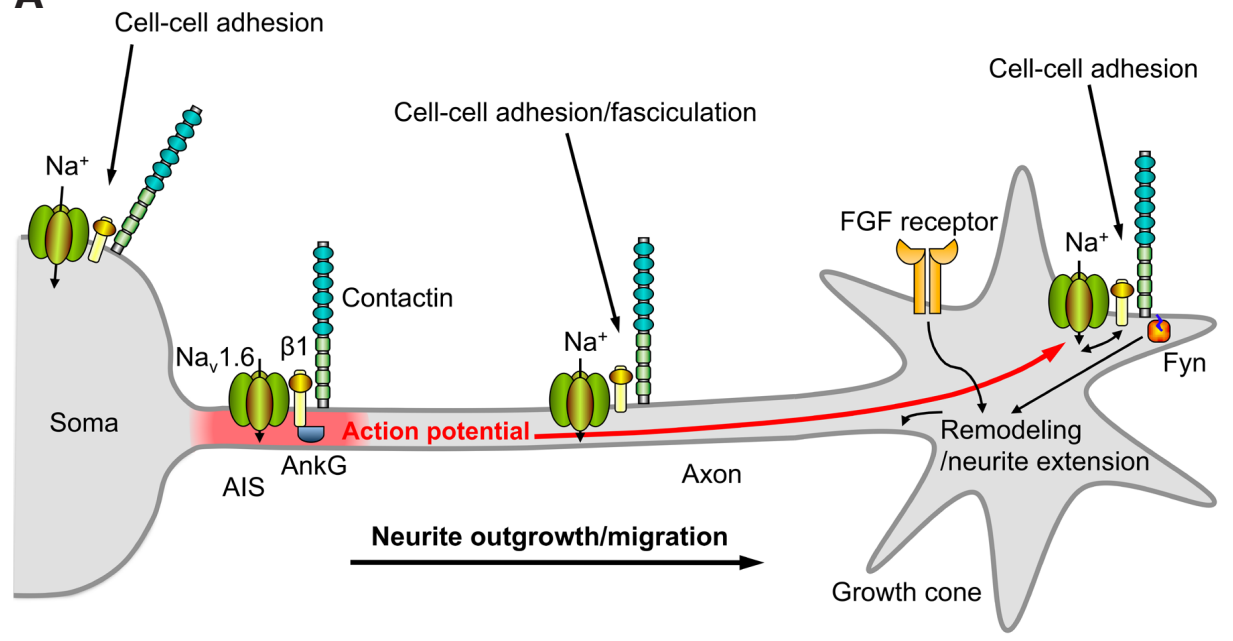

B

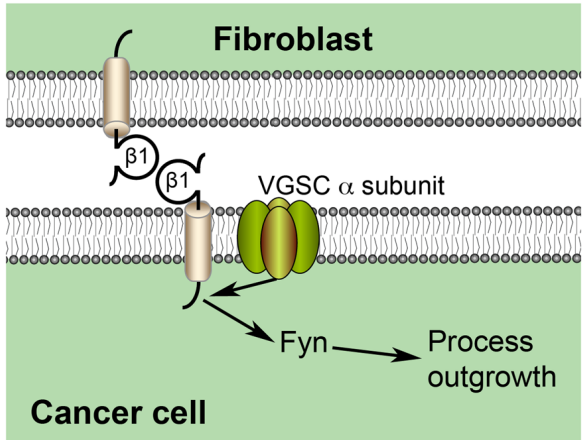

Fig. 3. Functional reciprocity between $\alpha$ and $\beta$ subunits regulating neurite outgrowth and migration during CNS development and metastasis. (A) $\beta 1$ is required for localization of $\mathrm{Na}_{v} 1.6$ to the axon initial segment and high frequency action potential firing. The electrical activity and resultant membrane depolarisation promotes $\beta 1$-mediated neurite outgrowth towards the growth cone. (B) $A$ similar mechanism is proposed for $\beta 1$-mediated process outgrowth in breast cancer cells. $\beta 1$ from an adjacent fibroblast or cancer cell interacts with $\beta 1$ on the cancer cell, initiating a signalling cascade that requires $\mathrm{Na}^{+}$current and fyn kinase. Figure panels reproduced with permission (Brackenbury et al., 2010, Nelson et al., 2014).
Interestingly, Scn2b deletion is neuroprotective in the experimental allergic encephalomyelitis MS model in mice, possibly by reducing $\alpha$ subunit up-regulation (O'Malley et al., 2009).

The $\beta$ subunits also play critical roles in CNS development. $S c n 1 b$ null mice are ataxic and display spontaneous generalized seizures (Chen et al., 2004). Mutations in SCN1B result in genetic epilepsy with febrile seizures plus (GEFS+;OMIM 604233; reviewed in (Patino and Isom, 2010). In cerebellar granule neurons (CGNs), $\beta 1$ promotes neurite outgrowth via trans-homophilic adhesion (Davis et al., 2004). $\beta 1$-mediated neurite outgrowth also requires fyn and contactin (Brackenbury et al., 2008a). In addition, $\beta$ natally developing CNS (Brackenbury et al., 2008a, Brackenbury et al., 2013). $\beta 1 \mathrm{~B}$ can also promote neurite outgrowth (Patino et 2011). $\beta 1$ is required for normal localization of $\mathrm{Na}_{v} 1.6$ to the rent is required for $\beta 1$ mediated neurite outgrowth suggesting a specific reciprocal relationship between these two subunits (Fig. 3A) (Brackenbury et al., 2010).

Scn2b null mice appear normal in neurological tests, although they display increased seizure susceptibility, and altered sensitivity to pain stimuli (Chen et al., 2002, LopezSantiago et al., 2006). Electrical activity is reduced in the optic nerve of $S c n 2 b$ null mice, and $\mathrm{Na}^{+}$current is reduced in hippocampal and dorsal root ganglion neurons, compared to wildtype animals (Chen et al., 2002, Lopez-Santiago et al., 2006). Scn3b null mice have altered cardiac function but show no abnormalities in the CNS (Hakim et al., 2008) It is possible that $\beta 1$ may compensate for the lack of $\beta 3$ allowing for an apparently normal neurological phenotype. Overexpression of $\beta 4$ in Neuro2a cells increases neurite outgrowth, dendrite formation, and filopodia-like protrusions (Oyama et al., 2006), suggesting that, like $\beta 1, \beta 4$ may regulate migration and pathfinding in vivo.

The $\beta$ subunits may play a role in downstream signalling pathways and gene transcription. The $\beta$ subunits are substrates for proteolytic processing by $\alpha, \beta$ and $\gamma$-secretases (Kim et al., 2005, Wong et al., 2005). Sequential cleavage of $\beta 2$ by $\beta$-secretase (BACE1) and $\gamma$-secretase release the $\beta 2$ intracellular domain, which is proposed to translocate to the nucleus and regulate expression of Nav1.1 (Kim et al., 2007, Kim et al., 2005). Secretase-mediated cleavage of $\beta 1$ regulates neurite outgrowth, suggesting that proteolytic processing of $\beta$ subunits may be an essential step in transducing the adhesion signal to promote migration (Brackenbury and Isom, 2011).

In summary, VGSC $\alpha$ and $\beta$ subunit expression is temporally regulated during CNS development. Regulated expression of specific subtypes is critical for maintaining 
A

(i)

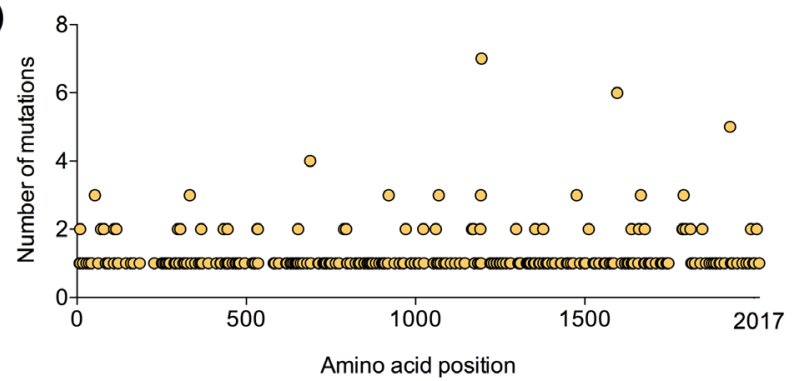

(ii)

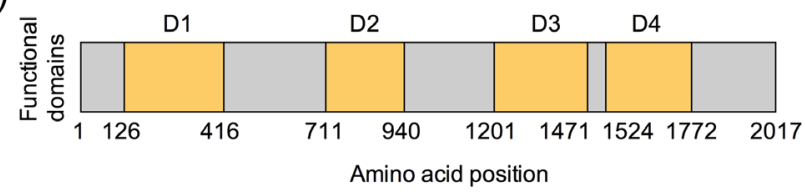

(iii)

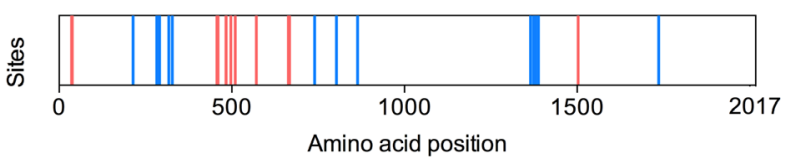

B

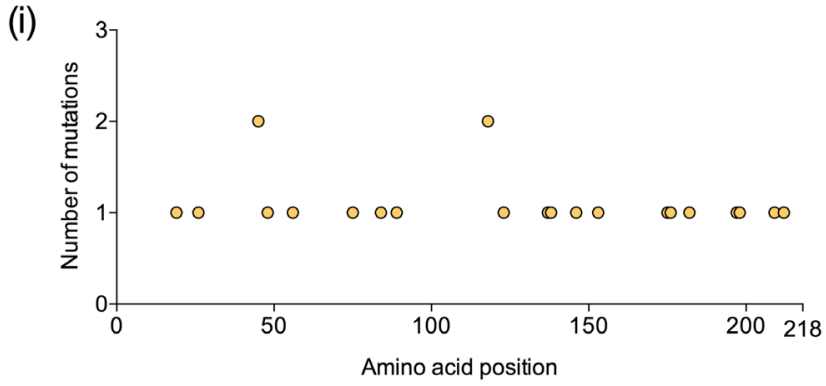

(ii)

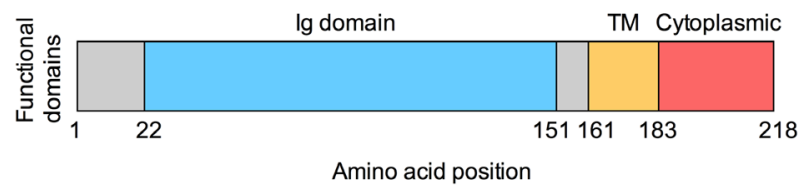

(iii)

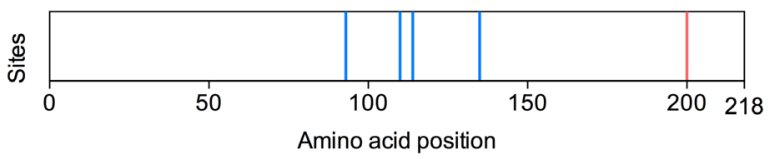

Fig. 4. $\mathbf{N a}_{\mathbf{v}} \mathbf{1 . 5}$ and $\mathbf{\beta 1}$ mutations in cancer. (A) $\mathrm{Na}_{\mathrm{v}}$. .5 : (i) Number of mutations reported in the COSMIC database (http://cancer.sanger.ac.uk/cancergenome/projects/cosmic/) for each amino acid position on $x$-axis. (ii) Location of Domains 1-4 (yellow) (Catterall, 2000). (iii) Putative phosphorylation (red) and glycosylation sites (blue). (B) $\beta 1$ : (i) Number of mutations reported in the COSMIC database for each amino acid position. (ii) Location of immunoglobulin (Ig) domain (blue), transmembrane (TM) domain (yellow) and cytoplasmic domain (red) (Brackenbury and Isom, 2011). (iii) Phosphorylation (red) and glycosylation sites (blue).

electrical excitability and activity-dependent synaptic connections on the one hand, and adhesive interactions, neurite outgrowth, fasciculation and migration on the other. Several studies point towards a potential causal relationship between altered VGSC expression, developmental aberrations, and CNS pathophysiologies, which requires further investigation.

\section{VGSCs and cancer}

\section{$\alpha$ subunits}

VGSC $\alpha$ subunits are widely expressed in a range of different types of cancer, including breast cancer, cervical cancer, colon cancer, glioma, leukaemia, lung cancer, lymphoma, melanoma, mesothelioma, neuroblastoma, ovarian cancer, and prostate cancer (Table 1A) (Brackenbury, 2012). Although the majority of evidence is based on studies using cell lines cultured in vitro, a number of reports have now confirmed that $\alpha$ subunit expression occurs in tumours in vivo, e.g. (Fraser et al., 2005, Gao et al., 2010, Hernandez-Plata et al., 2012, House et al., 2010). In several cancers where multiple $\alpha$ subunits have been detected, one $\alpha$ subunit has been identified as most highly expressed, e.g. $\mathrm{Na}_{\mathrm{v}} 1.5$ is predominant in breast cancer (Fraser et al., 2005), whereas $\mathrm{Na}_{v} 1.7$ is predominant in prostate cancer (Diss et al., 2004). Interestingly, $\mathrm{Na}_{v} 1.5$ and $\mathrm{Na}_{\mathrm{v}} 1.7$ have been shown to be mainly expressed in their neonatal DI:S3 splice forms in several cancers (Brackenbury, 2012). However, this splicing pattern is not conserved across all the tumour types studied, e.g., the neonatal DI:S3 splice form is absent in colon cancer cells, and the adult variant is expressed instead (House et al., 2010). There also appears to be a cancer type-specific relationship between $\alpha$ subunit expression and metastatic propensity. For example, $\mathrm{Na}_{v} 1.5$ is more highly expressed in strongly metastatic MDA-MB-231 breast cancer cells than weakly metastatic MCF-7 cells, and elevated $\mathrm{Na}_{v} 1.5$ expression in tumours correlates with increased risk of recurrence, metastasis and reduced overall survival (Fraser et al., 2005, Yang et al., 2012). A similar pattern has been shown for $\alpha$ subunit expression in colon, prostate and ovarian cancers. However, there is an inverse correlation between $\alpha$ subunit expression and clinical grade in glioma, and no relationship has been found in lung cancer cell lines (reviewed in (Brackenbury, 2012).

The mechanisms by which VGSCs are up-regulated in cancer cells are not well understood. Several studies suggest that growth factors may play a role (Fraser et al., 2014). Epidermal growth factor (EGF) and nerve growth factor (NGF) both increase $\mathrm{Na}^{+}$current in prostate cancer cells, the latter via activation of protein kinase A (PKA) (Brackenbury and Djamgoz, 2007, Ding et al., 2008). Similarly, EGF signalling via the extracellular signal-regulated kinase (ERK) 1/2 pathway increases expression of $\mathrm{Na}_{v} 1.7$ and $\mathrm{Na}^{+}$ current (Campbell et al., 2013). In breast cancer cells, oestrogen increases $\mathrm{Na}^{+}$current, suggesting that steroid hormones may also regulate VGSC expression/activity (Fraser et al., 2010). Further fine-tuning of VGSC expression in cancer cells is achieved through positive feedback auto-regulation. In both metastatic breast and prostate cancer cells, $\mathrm{Na}^{+}$current activates PKA, which in turn, promotes functional expression of $\mathrm{Na}_{v} 1.5$ and $\mathrm{Na}_{v} 1.7$, respectively (Brackenbury and Djamgoz, 2006, Chioni et al., 2010).

In vitro, the $\alpha$ subunits have been shown to enhance various cellular behaviours associated with metastasis, including endocytosis 
(Mycielska et al., 2003), galvanotaxis (Djamgoz et al., 2001), gene expression (Mycielska et al., 2005), invasion (Grimes et al., 1995), migration (Fraser et al., 2003), and process outgrowth (Fraser et al., 1999) (Table2). Conflicting reports suggest that $\alpha$ subunits may, or may not, also regulate proliferation (Abdul and Hoosein, 2002, Fraser et al., 2000, Roger et al., 2003). These discrepancies may be due to the differing specificity of the various pharmacological approaches used in different studies. Several studies have indicated that specific $\alpha$ subunits contribute to the invasive capacity of different cancer cell types. For example, the neonatal DI:S3 splice variant of $\mathrm{Na}_{v} 1.5$ enhances migration and invasion of metastatic breast cancer cells (Brackenbury et al., 2007). In contrast, $\mathrm{Na}_{\mathrm{v}} 1.6$ enhances invasion of cervical cancer cells (Hernandez-Plata etal., 2012), and $\mathrm{Na}_{v} 1.6$ and $\mathrm{Na}_{v} 1.7$ enhance invasion and endocytosis in prostate cancer cells (Nakajima et al., 2009). Nonetheless, expression of any subtype may be sufficient to promote invasion. For example, overexpression of $\mathrm{Na}_{\mathrm{v}} 1.4$ increases the invasiveness of LNCaP prostate cancer cells (Bennett et al., 2004).

The fact that $\alpha$ subunits appear to be up-regulated in cancer cells and promote metastasis-like behaviour suggests that they may be useful therapeutic targets. Indeed, the VGSC-inhibiting drugs phenytoin and ranolazine have both recently been shown to inhibit metastasis in xenograft mouse models of breast cancer (Driffort et al., 2014, Nelson et al., 2015). In support of this, several other VGSC-targeting antiepileptic drugs, including phenytoin, carbamazepine and riluzole, have been shown to inhibit secretory activity, cellular migration, proliferation and invasion in cell lines from several different cancers (Abdul and Hoosein, 2001, Abdul and Hoosein, 2002, Fraser et al., 2003, Yang et al., 2012). Given that the membrane potential $\left(\mathrm{V}_{\mathrm{m}}\right)$ of cancer cells is relatively depolarised compared with terminally differentiated cells (Yang and Brackenbury, 2013), it is likely that the majority of VGSCs are in the inactivated state. Therefore, the persistent $\mathrm{Na}^{+}$current, which is typically a few per cent of the transient current, is likely to be predominant and may prove to be an important therapeutic target (Yang et al., 2012).

Several theories have been proposed to explain how $\mathrm{Na}^{+}$flux through VGSCs contributes to invasion and metastasis. In breast cancer cells, $\mathrm{Na}_{v} 1.5$-mediated $\mathrm{Na}^{+}$influx has been shown to increase $\mathrm{H}^{+}$efflux through the $\mathrm{Na}^{+} / \mathrm{H}^{+}$exchanger ( $\mathrm{NHE} 1$ ), causing intracellular alkalinisation and extracellular perimembrane acidification, thus enhancing the activity of $\mathrm{pH}$-dependent cathepsin proteases and

\section{TABLE 2}

\section{METASTATIC CELL BEHAVIOURS REGULATED BY VGSCs (BRACKENBURY, 2012)}

\begin{tabular}{|c|c|c|}
\hline Cellular activity & Cancer & Subunit(s) implicated \\
\hline Process outgrowth & Breast, prostate & $\mathrm{Na}_{\mathrm{v}} 1.5, \mathrm{Na}_{\mathrm{v}} 1.7, \beta 1$ \\
\hline Galvanotaxis & Breast, prostate & $\mathrm{Na}_{\mathrm{v}} 1.5, \mathrm{Na}_{\mathrm{v}} 1.7$ \\
\hline $\begin{array}{l}\text { Lateral motility (wound } \\
\text { healing) }\end{array}$ & Breast, mesothelioma, prostate & $\mathrm{Na}_{v} 1.5, \mathrm{Na}_{v} 1.7, \beta 1, \beta 2$ \\
\hline Transwell migration & Breast, prostate & $\mathrm{Na}_{\mathrm{v}} 1.5, \mathrm{Na}_{\mathrm{v}} 1.7$ \\
\hline $\begin{array}{l}\text { Endocytic membrane } \\
\text { activity }\end{array}$ & $\begin{array}{l}\text { Breast, prostate, small cell lung } \\
\text { cancer }\end{array}$ & $\mathrm{Na}_{\mathrm{v}} 1.5, \mathrm{Na}_{\mathrm{v}} 1.7$ \\
\hline Vesicular patterning & Breast, prostate & $\mathrm{Na}_{\mathrm{v}} 1.7$ \\
\hline Adhesion & Breast, prostate & $\mathrm{Na}_{\mathrm{v}} 1.5, \mathrm{Na}_{\mathrm{v}} 1.7, \beta 1, \beta 2$ \\
\hline Gene expression & Breast, colon, prostate & $\mathrm{Na}_{\mathrm{v}} 1.5, \mathrm{Na}_{\mathrm{v}} 1.7, \beta 1$ \\
\hline Invasion & $\begin{array}{l}\text { Breast, cervical, colon, lymphoma, } \\
\text { melanoma, non-small cell lung } \\
\text { cancer, prostate }\end{array}$ & $\mathrm{Na}_{v} 1.5, \mathrm{Na}_{v} 1.6, \mathrm{Na}_{v} 1.7, \beta 1, \beta 2$ \\
\hline
\end{tabular}

invadopodia formation (Brisson et al., 2013, Gillet et al., 2009). An additional possibility is that VGSCs may regulate gene expression (Brackenbury and Djamgoz, 2006). In colon cancer cells, $\mathrm{Na}_{v} 1.5$ has been proposed to be a key regulator of a network of invasionpromoting genes (House et al., 2010). However, the intermediate steps between $\mathrm{Na}^{+}$current and gene transcription remain to be elucidated. A third possibility is that VGSCs may regulate the intracellular $\mathrm{Ca}^{2+}$ level. For example, activation of VGSCs present on intracellular membranes in macrophages and melanoma cells causes $\mathrm{Na}^{+}$release from cationic stores, followed by $\mathrm{Na}^{+}$uptake by mitochondria, and $\mathrm{Ca}^{2+}$ release, which then increases podosome and invadopodia formation, and enhanced invasiveness (Carrithers et al., 2009). Finally, a significant number of somatic mutations have been identified in SCN5A in tumours (Fig. 4A), which span all functional domains (Fig. 1). Further work is required to establish whether and how these mutations may confer a functional advantage on the VGSC to promote invasive behaviour.

\section{$\beta$ subunits}

VGSC $\beta$ subunits have been detected in prostate, breast, lung, and cervical cancers (Table 1B) (Brackenbury, 2012). Subtypespecific expression varies across cancer types: $\beta 3$ is present in prostate and lung cancer cells, but is absent in breast and cervical cancer cells. In contrast, $\beta 1$ is predominant in breast, prostate, and cervical cancer cells (Chioni et al., 2009, Diss et al., 2008, Hernandez-Plata et al., 2012). Similar to SCN5A, a number of somatic mutations have been identified in SCN1B in tumours (Fig. 4B), in both the immunoglobulin and cytoplasmic domains (Fig. 2). $\beta 1$ and $\beta 2$ expression levels correlate with metastatic potential in prostate cancer (Diss et al., 2008, Jansson et al., 2012). However, this pattern is not reflected in breast cancer (Chioni et al., 2009, Nelson et al., 2014). Thus, $\beta$ subunit expression may vary across cancer type and grade, dependent on specific functional specialisations and heterotypic interactions.

In breast cancer cell lines cultured in vitro, $\beta 1$ enhances cellcell and cell-substrate adhesion, and retards migration in wound healing and transwell assays (Chioni et al., 2009). In an orthotopic mouse model of breast cancer, $\beta 1$ overexpression increases tumour growth and metastasis (Nelson et al., 2014). $\beta 1$ overexpression also increases vascular endothelial growth factor (VEGF) secretion and angiogenesis, and reduces apoptosis. Interestingly, $\beta 1$ promotes neurite-like process outgrowth from breast cancer cells via trans-homophilic adhesion, thus recapitulating its functional role in neurons (Fig. 3A) (Davis et al., 2004, Nelson et al., 2014). As in neurons, $\beta 1$-mediate process outgrowth in breast cancer cells requires fyn kinase activity and $\mathrm{Na}^{+}$current (Fig. 3B) (Brackenbury et al., 2010, Brackenbury et al., 2008a). Thus, it appears that $\beta 1$ plays parallel roles in regulating neuronal migration during CNS development, on the one hand, and cancer cell invasion during metastasis, on the other. Therefore, targeting the adhesive function of $\beta 1$ may provide a novel approach to anti-cancer therapy (Brackenbury and Isom, 2008).

In LNCaP prostate cancer cells, over-expression of $\beta 2$ induces a bipolar morphology and increases overall length with a concurrent reduction in volume (Jansson et al., 2012). These changes could allow for greater invasion and motility. In agreement with this, $\beta 2$ over-expressing cells have increased migratory capability compared to control cells in a wound healing assay (Jansson et al., 2012). $\beta 2$ over-expressing cells plated on various substrates 
Fig. 5. A model for VGSC involvement in cancer progression. $\beta$ subunits are expressed in proliferating primary tumours, contributing to adhesion (Chioni et al., 2009), and in the case of $\beta 1$, promoting angiogenesis and resistance to apoptosis (Nelson et al., 2014). Up-regulation of $\alpha$ subunits, e.g. $\mathrm{Na}_{v} 1.5$, promotes a mesenchymal-like phenotype (Brisson et al., 2013, Nelson et al., 2014), activation of proteases (Gilletet al., 2009) and local invasion from the primary tumour (Brackenbury et al., 2007, Fraser et al., 2005, Roger et al., 2003). VGSC-expressing cells subsequently intravasate and metastasise to distant sites (Fraser et al., 2005, Jansson et al., 2012, Nelson et al., 2014). Figure adapted with permission (Brackenbury et al., 2008b).

preferentially adhere to vitronectin and Matrigel over fibronectin, suggesting that $\beta 2$ may selectively increase adhesion dependent on the surrounding tissue/substrate (Jansson et al., 2012). In contrast, $\beta 2$ over-expression reduces tumour take and growth following subcutaneous implantation of LNCaP cells into nude mice (Jansson et al., 2012). Thus, $\beta 2$ may enhance invasion and metastasis whilst also reducing the ability of tumours to form localized masses. In support of this notion, $\beta 2$ over-expression increases invasion and growth on laminin, and enhances association between prostate cancer cells and nerve axons in organotypic cultures (Jansson et al., 2014). Therefore, $\beta 2$ may permit association between prostate cancer cells and neural matrices, enhancing perineural invasion, thus enabling glandular egress and subsequent metastatic dissemination.

In contrast to $\beta 1$ and $\beta 2, \beta 3$ may function as a tumour suppressor. SCN3B (encoding $\beta 3$ ) contains two functional p53 response elements, suggesting that it may be directly regulated by the tumour suppressor p53 (Adachi et al., 2004). In addition, Scn3b

is up-regulated in wildtype mouse embryo fibroblasts (MEFs), but not $p 53$ null MEFs following treatment with adriamycin (Adachi et al., 2004). Furthermore, $\beta 3$ suppresses colony formation, and in association with various anticancer agents, $\beta 3$ promotes apoptosis in a p53-dependent manner (Adachi et al., 2004).

Less is known about the expression/function of $\beta 4$ in cancers. Interestingly, a strong down-regulation of $\beta 4$ has been reported in primary cultures of cervical cancer cells relative to cells from noncancerous cervix (Hernandez-Plata et al., 2012). A similar pattern of expression has also been reported in prostate cancer cell lines (Diss et al., 2008). However, $\beta 4$ expression is increased in cervical cancer biopsies compared to noncancerous cervix. This difference in relative expression levels between biopsies and primary cell cultures may be due to the adhesive function differing in vivo as opposed to in vitro (Hernandez-Plata et al., 2012). Further work is required to investigate this possibility.

In summary, VGSCs are up-regulated in a number of different types of cancer. Increasing evidence suggests that $\alpha$ and $\beta$ subunits both play an important role in promoting various aspects of cancer progression and metastasis (Fig. 5). The role(s) played by specific subtypes appears to be complex, and may be dependent on tumour type. A common theme is that $\alpha$ subunits regulate invasion via $\mathrm{Na}^{+}$ current, whereas $\beta$ subunits regulate adhesion interactions. The

\section{Proliferation}

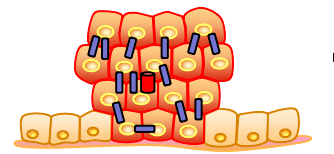

Promotion of primary tumour growth and angiogenesis, e.g. by $\beta 1$ subunits.
VGSC-expressing cells migrate and invade membrane into and disseminate to form metastases.

\section{Detachment and migration}

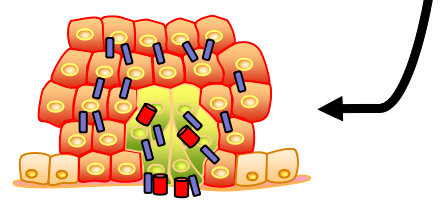

Selective up-regulation of $\alpha$ subunits, e.g. $\mathrm{Na}_{\mathrm{v}} 1.5$, enhances mesenchymal-like invasive phenotype and promotes $\beta 1$ mediated process outgrowth.

\begin{tabular}{|c|l|}
\hline 0 & Normal cell \\
0 & Invasive cell \\
0 & $\beta$ subunit, e.g. $\beta 1$ \\
0 & $\alpha$ subunit, e.g. $\mathrm{Na}_{\mathrm{v}} 1.5$ \\
\hline
\end{tabular}

next step is to establish the extent and distribution of expression of VGSCs across tumour types, and the precise involvement of different $\alpha$ and $\beta$ subunits, with the goal of harnessing their therapeutic potential.

\section{Conclusions}

VGSCs function as macromolecular signalling complexes in which $\mathrm{Na}^{+}$current through the $\alpha$ subunit pore is coupled with nonconducting signalling via the $\beta$ subunits. For example, in migrating neurons, complexes of $\mathrm{Na}_{v} 1.6, \beta 1$, fyn and contactin are proposed to localise to the growth come, regulating neurite outgrowth and migration (Brackenbury et al., 2010, Brackenbury et al., 2008a). Similarly, complexes of $\mathrm{Na}_{\mathrm{v}} 1.5$ and $\beta 1$ may occur in breast cancer cells, regulating morphological changes and metastasis (Nelson et al., 2014, Yang et al., 2012). Additional complexity may be provided by further interactions with the cytoskeleton, e.g. via ankyrin, and secretases (Brackenbury and Isom, 2011, Kim et al., 2005, Malhotra et al., 2000). The challenge now is to understand how signalling through these complexes gives rise to morphological changes and cellular motility, and how variations in the composition of the complex might relate to cell/tissue type, functional specialisation and subcellular domain. An important observation is that VGSC 
$\alpha$ and $\beta$ subunits appear to play multifunctional and parallel roles (1) in excitable cells, e.g. CNS neurons, and (2) in metastatic cancer cells, regulating $\mathrm{Na}^{+}$current, migration and invasion in both systems. It is therefore essential to better understand the identity, function and composition of these complexes during development and in pathophysiological situations. An intriguing possibility is that VGSCs may be useful prognostic markers, and/or novel therapeutic targets for reducing/preventing metastasis.

\section{Acknowledgements}

This work was supported by the Medical Research Council [grant numbers MR/K016296/1 and G1000508].

\section{References}

ABDUL, M. and HOOSEIN, N. (2001). Inhibition by anticonvulsants of prostate-specific antigen and interleukin-6 secretion by human prostate cancer cells. Anticancer Res. 21: 2045-2048.

ABDUL, M. and HOOSEIN, N. (2002). Voltage-gated sodium ion channels in prostate cancer: expression and activity. Anticancer Res. 22: 1727-1730.

ADACHI, K., TOYOTA, M., SASAKI, Y., YAMASHITA, T., ISHIDA, S., OHE-TOYOTA, M., MARUYAMA, R., HINODA, Y., SAITO, T., IMAI, K. et al., (2004). Identification of SCN3B as a novel p53-inducible proapoptotic gene. Oncogene 23: 7791-7798.

BECKH, S., NODA, M., LUBBERT, H. and NUMA, S. (1989). Differential regulation of three sodium channel messenger RNAs in the rat central nervous system during development. EMBO J. 8: 3611-3616.

BENNETT, E.S., SMITH, B.A. and HARPER, J.M. (2004). Voltage-gated $\mathrm{Na}^{+}$channels confer invasive properties on human prostate cancer cells. Pflugers Arch. 447: 908-914

BLACK, J.A., DIB-HAJJ, S., BAKER, D., NEWCOMBE, J., CUZNER, M.L. and WAXMAN, S.G. (2000). Sensory neuron-specific sodium channel SNS is abnormally expressed in the brains of mice with experimental allergic encephalomyelitis and humans with multiple sclerosis. Proc. Natl. Acad. Sci. USA 97: 11598-11602.

BOIKO, T., RASBAND, M.N., LEVINSON, S.R., CALDWELL, J.H., MANDEL, G., TRIMMER, J.S. and MATTHEWS, G. (2001). Compact myelin dictates the differential targeting of two sodium channel isoforms in the same axon. Neuron 30: 91-104.

BOIKO, T., VAN WART, A., CALDWELL, J.H., LEVINSON, S.R., TRIMMER, J.S. and MATTHEWS, G. (2003). Functional specialization of the axon initial segment by isoform-specific sodium channel targeting. J. Neurosci. 23: 2306-2313.

BRACKENBURY, W.J. (2012). Voltage-gated sodium channels and metastatic disease. Channels (Austin) 6: 352-361.

BRACKENBURY, W.J., CALHOUN, J.D., CHEN, C., MIYAZAKI, H., NUKINA, N., OYAMA, F., RANSCHT, B. and ISOM, L.L. (2010). Functional reciprocity between $\mathrm{Na}+$ channel Nav1.6 and $\beta 1$ subunits in the coordinated regulation of excitability and neurite outgrowth. Proc. Natl. Acad. Sci. USA 107: 2283-2288.

BRACKENBURY, W.J., CHIONI, A.M., DISS, J.K. and DJAMGOZ, M.B. (2007). The neonatal splice variant of Nav1.5 potentiates in vitro metastatic behaviour of MDA-MB-231 human breast cancer cells. Breast Cancer Res. Treat. 101:149-160.

BRACKENBURY, W.J., DAVIS, T.H., CHEN, C., SLAT, E.A., DETROW, M.J., DICKENDESHER, T.L., RANSCHT, B. and ISOM, L.L. (2008a). Voltage-gated $\mathrm{Na}^{+}$ channel $\beta 1$ subunit-mediated neurite outgrowth requires fyn kinase and contributes to central nervous system development in vivo. J. Neurosci. 28: 3246-3256.

BRACKENBURY, W.J. and DJAMGOZ, M.B. (2006). Activity-dependent regulation of voltage-gated $\mathrm{Na}^{+}$channel expression in Mat-LyLu rat prostate cancer cell line. J. Physiol. 573: 343-356.

BRACKENBURY, W.J. and DJAMGOZ, M.B. (2007). Nerve growth factor enhances voltage-gated $\mathrm{Na}+$ channel activity and Transwell migration in Mat-LyLu rat prostate cancer cell line. J. Cell. Physiol. 210: 602-608.

BRACKENBURY, W.J., DJAMGOZ, M.B. and ISOM, L.L. (2008b). An emerging role for voltage-gated $\mathrm{Na}+$ channels in cellular migration: regulation of central nervous system development and potentiation of invasive cancers. Neuroscientist 14: $571-583$

BRACKENBURY, W.J. and ISOM, L.L. (2008). Voltage-gated Na+ channels: potentia for beta subunits as therapeutic targets. Expert Opin. Ther. Targets 12: 1191-1203.
BRACKENBURY, W.J. and ISOM, L.L. (2011). Na Channel beta Subunits: Overachievers of the Ion Channel Family. Front. Pharmacol. 2: 53.

BRACKENBURY, W.J., YUAN, Y., O'MALLEY, H.A., PARENT, J.M. and ISOM, L.L. (2013). Abnormal neuronal patterning occurs during early postnatal brain development of Scn1b-null mice and precedes hyperexcitability. Proc. Natl. Acad. Sci. USA 110: 1089-1094.

BRISSON, L., DRIFFORT, V., BENOIST, L., POET, M., COUNILLON, L., ANTELMI, E., RUBINO, R., BESSON, P., LABBAL, F., CHEVALIER, S. et al., (2013). NaV1.5 $\mathrm{Na}(+)$ channels allosterically regulate the NHE-1 exchanger and promote the activity of breast cancer cell invadopodia. J. Cell Sci. 126: 4835-4842.

CAMPBELL, T.M., MAIN, M.J. and FITZGERALD, E.M. (2013). Functional expression of the voltage-gated $\mathrm{Na}(+)$-channel $\mathrm{Nav1} .7$ is necessary for EGF-mediated invasion in human non-small cell lung cancer cells. J. Cell Sci. 126: 4939-4949.

CARRITHERS, M.D., CHATTERJEE, G., CARRITHERS, L.M., OFFOHA, R., IHEAGWARA, U., RAHNER, C., GRAHAM, M. and WAXMAN, S.G. (2009). Regulation of podosome formation in macrophages by a novel splice variant of the sodium channel SCN8A. J. Biol. Chem. 284: 8114-8126.

CASAGRANDE, V.A. and CONDO, G.J. (1988). The effect of altered neuronal activity on the development of layers in the lateral geniculate nucleus. J. Neurosci. 8: 395-416.

CATTERALL, W.A. (2000). From ionic currents to molecular mechanisms: the structure and function of voltage-gated sodium channels. Neuron 26: 13-25.

CHEN, C., BHARUCHA, V., CHEN, Y., WESTENBROEK, R.E., BROWN, A., MALHOTRA, J.D., JONES, D., AVERY, C., GILLESPIE, P.J., 3RD, KAZEN-GILLESPIE, K.A. et al., (2002). Reduced sodium channel density, altered voltage dependence of inactivation, and increased susceptibility to seizures in mice lacking sodium channel beta 2-subunits. Proc. Natl. Acad. Sci. USA 99: 17072-17077.

CHEN, C., WESTENBROEK, R.E., XU, X., EDWARDS, C.A., SORENSON, D.R., CHEN, Y., MCEWEN, D.P., O'MALLEY, H.A., BHARUCHA, V., MEADOWS, L.S. et al., (2004). Mice lacking sodium channel beta1 subunits display defects in neuronal excitability, sodium channel expression, and nodal architecture. $J$ Neurosci. 24: 4030-4042.

CHIONI, A.M., BRACKENBURY, W.J., CALHOUN, J.D., ISOM, L.L. and DJAMGOZ, M.B. (2009). A novel adhesion molecule in human breast cancer cells: voltagegated $\mathrm{Na}+$ channel beta1 subunit. Int. J. Biochem. Cell Biol. 41: 1216-1227.

CHIONI, A.M., SHAO, D., GROSE, R. and DJAMGOZ, M.B. (2010). Protein kinase A and regulation of neonatal Nav1.5 expression in human breast cancer cells: activity-dependent positive feedback and cellular migration. Int. J. Biochem. Cell Biol. 42: 346-358.

CHOPRA, S.S., STROUD, D.M., WATANABE, H., BENNETT, J.S., BURNS, C.G. WELLS, K.S., YANG, T., ZHONG, T.P. and RODEN, D.M. (2010). Voltage-gated sodium channels are required for heart development in zebrafish. Circ. Res. 106: $1342-1350$.

CRANER, M.J., NEWCOMBE, J., BLACK, J.A., HARTLE, C., CUZNER, M.L. and WAXMAN, S.G. (2004). Molecular changes in neurons in multiple sclerosis: altered axonal expression of Nav1.2 and Nav1.6 sodium channels and $\mathrm{Na}^{+} / \mathrm{Ca}^{2+}$ exchanger. Proc. Natl. Acad. Sci. USA 101: 8168-8173.

CUSDIN, F.S., NIETLISPACH, D., MAMAN, J., DALE, T.J., POWELL, A.J., CLARE, J.J. and JACKSON, A.P. (2010). The sodium channel \{beta\}3-subunit induces multiphasic gating in NaV1.3 and affects fast inactivation via distinct intracellular regions. J. Biol. Chem. 285: 33404-33412.

DAVIS, T.H., CHEN, C. and ISOM, L.L. (2004). Sodium channel beta1 subunits promote neurite outgrowth in cerebellar granule neurons. J. Biol. Chem. 279:51424-51432.

DESCHENES, I., ARMOUNDAS, A.A., JONES, S.P. and TOMASELLI, G.F. (2008). Post-transcriptional gene silencing of KChIP2 and Navbeta1 in neonatal rat cardiac myocytes reveals a functional association between $\mathrm{Na}$ and Ito currents. J. Mol. Cell. Cardiol. 45: 336-346.

DESCHENES, I. and TOMASELLI, G.F. (2002). Modulation of Kv4.3 current by accessory subunits. FEBS Lett. 528: 183-188.

DING, Y., BRACKENBURY, W.J., ONGANER, P.U., MONTANO, X., PORTER, L.M., BATES, L.F. and DJAMGOZ, M.B. (2008). Epidermal growth factor upregulates motility of Mat-LyLu rat prostate cancer cells partially via voltage-gated $\mathrm{Na}^{+}$channel activity. J. Cell. Physiol. 215: 77-81.

DISS, J.K., FRASER, S.P. and DJAMGOZ, M.B. (2004). Voltage-gated $\mathrm{Na}^{+}$channels: multiplicity of expression, plasticity, functional implications and pathophysiological aspects. Eur. Biophys. J. 33: 180-193.

DISS, J.K., FRASER, S.P., WALKER, M.M., PATEL, A., LATCHMAN, D.S. and 
DJAMGOZ, M.B. (2008). Beta-subunits of voltage-gated sodium channels in human prostate cancer: quantitative in vitro and in vivo analyses of mRNA expression. Prostate Cancer Prostatic Dis. 11: 325-333.

DJAMGOZ, M.B.A., MYCIELSKA, M., MADEJA, Z., FRASER, S.P. and KOROHODA, W. (2001). Directional movement of rat prostate cancer cells in direct-current electric field: involvement of voltage gated $\mathrm{Na}^{+}$channel activity. J. Cell Sci. 114:2697-2705.

DRIFFORT, V., GILLET, L., BON, E., MARIONNEAU-LAMBOT, S., OULLIER, T., JOULIN, V., COLLIN, C., PAGES, J.C., JOURDAN, M.L., CHEVALIER, S. et al., (2014). Ranolazine inhibits NaV1.5-mediated breast cancer cell invasiveness and lung colonization. Mol. Cancer 13: 264

FRASER, S.P., DING, Y., LIU, A., FOSTER, C.S. and DJAMGOZ, M.B. (1999). Tetrodotoxin suppresses morphological enhancement of the metastatic MAT-LyLu rat prostate cancer cell line. Cell Tissue Res. 295: 505-512.

FRASER, S.P., DISS, J.K., CHIONI, A.M., MYCIELSKA, M.E., PAN, H., YAMACI, R.F., PANI, F., SIWY, Z., KRASOWSKA, M., GRZYWNA, Z. et al., (2005). Voltage-gated sodium channel expression and potentiation of human breast cancer metastasis. Clin. Cancer. Res. 11: 5381-5389.

FRASER, S.P., GRIMES, J.A. and DJAMGOZ, M.B. (2000). Effects of voltage-gated ion channel modulators on rat prostatic cancer cell proliferation: comparison of strongly and weakly metastatic cell lines. Prostate 44: 61-76.

FRASER, S.P., OZERLAT-GUNDUZ, I., BRACKENBURY, W.J., FITZGERALD, E.M., CAMPBELL, T.M., COOMBES, R.C. and DJAMGOZ, M.B. (2014). Regulation of voltage-gated sodium channel expression in cancer: hormones, growth factors and auto-regulation. Philos. Trans. R. Soc. Lond. B Biol. Sci. 369: 20130105.

FRASER, S.P., OZERLAT-GUNDUZ, I., ONKAL, R., DISS, J.K., LATCHMAN, D.S. and DJAMGOZ, M.B. (2010). Estrogen and non-genomic upregulation of voltagegated $\mathrm{Na}(+)$ channel activity in MDA-MB-231 human breast cancer cells: role in adhesion. J. Cell. Physiol. 224: 527-539.

FRASER, S.P., SALVADOR, V., MANNING, E.A., MIZAL, J., ALTUN, S., RAZA, M., BERRIDGE, R.J. and DJAMGOZ, M.B. (2003). Contribution of functional voltagegated $\mathrm{Na}^{+}$channel expression to cell behaviors involved in the metastatic cascade in rat prostate cancer: I. lateral motility. J. Cell. Physiol. 195: 479-487.

GAO, R., SHEN, Y., CAI, J., LEI, M. and WANG, Z. (2010). Expression of voltage-gated sodium channel alpha subunit in human ovarian cancer. Oncol. Rep. 23: 1293-1299.

GILCHRIST, J., DAS, S., VAN PETEGEM, F. and BOSMANS, F. (2013). Crystallographic insights into sodium-channel modulation by the beta4 subunit. Proc. Natl. Acad. Sci. USA 110: E5016-E5024.

GILLET, L., ROGER, S., BESSON, P., LECAILLE, F., GORE, J., BOUGNOUX, P., LALMANACH, G. and LE GUENNEC, J.Y. (2009). Voltage-gated Sodium Channel Activity Promotes Cysteine Cathepsin-dependent Invasiveness and Colony Growth of Human Cancer Cells. J. Biol. Chem. 284: 8680-8691.

GOLDIN, A.L., BARCHI, R.L., CALDWELL, J.H., HOFMANN, F., HOWE, J.R., HUNTER, J.C., KALLEN, R.G., MANDEL, G., MEISLER, M.H., NETTER, Y.B. et al., (2000). Nomenclature of voltage-gated sodium channels. Neuron28:365-368.

GRIECO, T.M., MALHOTRA, J.D., CHEN, C., ISOM, L.L. and RAMAN, I.M. (2005). Open-channel block by the cytoplasmic tail of sodium channel b4 as a mechanism for resurgent sodium current. Neuron 45: 233-244.

GRIMES, J.A., FRASER, S.P., STEPHENS, G.J., DOWNING, J.E., LANIADO, M.E., FOSTER, C.S., ABEL, P.D. and DJAMGOZ, M.B. (1995). Differential expression of voltage-activated $\mathrm{Na}^{+}$currents in two prostatic tumour cell lines: contribution to invasiveness in vitro. FEBS Lett. 369: 290-294.

HAKIM, P., GURUNG, I.S., PEDERSEN, T.H., THRESHER, R., BRICE, N., LAWRENCE, J., GRACE, A.A. and HUANG, C.L. (2008). Scn3b knockout mice exhibit abnormal ventricular electrophysiological properties. Prog. Biophys. Mol. Biol. 98: 251-66.

HARRIS, J.B. and POLLARD, S.L. (1986). Neuromuscular transmission in the murine mutants "motor end-plate disease" and "jolting". J. Neurol. Sci. 76: 239-253.

HERNANDEZ-PLATA, E., ORTIZ, C.S., MARQUINA-CASTILLO, B., MEDINAMARTINEZ, I., ALFARO, A., BERUMEN, J., RIVERA, M. and GOMORA, J.C. (2012). Overexpression of $\mathrm{Na}(\mathrm{V}) 1.6$ channels is associated with the invasion capacity of human cervical cancer. Int. J. Cancer 130: 2013-2023.

HILLE, B. (1992). Ionic channels of excitable membranes. Sinauer Associates Inc., Sunderland (Massachusetts).

HOUSE, C.D., VASKE, C.J., SCHWARTZ, A., OBIAS, V., FRANK, B., LUU, T., SARVAZYAN, N., IRBY, R.B., STRAUSBERG, R.L., HALES, T. et al., (2010). Voltage-gated $\mathrm{Na}+$ channel SCN5A is a key regulator of a gene transcriptional network that controls colon cancer invasion. Cancer Res. 70: 6957-6967.

ISHIKAWA, T., TAKAHASHI, N., OHNO, S., SAKURADA, H., NAKAMURA, K., ON, Y.K., PARK, J.E., MAKIYAMA, T., HORIE, M., ARIMURA, T. et al., (2013). Novel SCN3B mutation associated with brugada syndrome affects intracellular trafficking and function of Nav1.5. Circ. J. 77: 959-967.

ISOM, L.L., DE JONGH, K.S., PATTON, D.E., REBER, B.F., OFFORD, J., CHARBONNEAU, H., WALSH, K., GOLDIN, A.L. and CATTERALL, W.A. (1992). Primary structure and functional expression of the beta1 subunit of the rat brain sodium channel. Science 256: 839-842.

ISOM, L.L., RAGSDALE, D.S., DE JONGH, K.S., WESTENBROEK, R.E., REBER, B.F., SCHEUER, T. and CATTERALL, W.A. (1995). Structure and function of the b2 subunit of brain sodium channels, a transmembrane glycoprotein with a CAM motif. Cell 83: 433-442.

JANSSON, K.H., CASTILLO, D.G., MORRIS, J.W., BOGGS, M.E., CZYMMEK, K.J., ADAMS, E.L., SCHRAMM, L.P. and SIKES, R.A. (2014). Identification of beta-2 as a key cell adhesion molecule in PCa cell neurotropic behavior: a novel ex vivo and biophysical approach. PLoS One 9: e98408.

JANSSON, K.H., LYNCH, J.E., LEPORI-BUI, N., CZYMMEK, K.J., DUNCAN, R.L. and SIKES, R.A. (2012). Overexpression of the VSSC-associated CAM, beta-2, enhances LNCaP cell metastasis associated behavior. Prostate 72: 1080-1092.

KAPLAN, M.R., CHO, M.H., ULLIAN, E.M., ISOM, L.L., LEVINSON, S.R. and BARRES, B.A. (2001). Differential control of clustering of the sodium channels $\mathrm{Na}(\mathrm{v}) 1.2$ and $\mathrm{Na}(\mathrm{v}) 1.6$ at developing CNS nodes of Ranvier. Neuron 30: 105-119.

KAZARINOVA-NOYES, K., MALHOTRA, J.D., MCEWEN, D.P., MATTEI, L.N., BERGLUND, E.O., RANSCHT, B., LEVINSON, S.R., SCHACHNER, M., SHRAGER, P., ISOM, L.L. et al., (2001). Contactin associates with $\mathrm{Na}^{+}$channels and increases their functional expression. J. Neurosci. 21: 7517-7525.

KAZEN-GILLESPIE, K.A., RAGSDALE, D.S., D’ANDREA, M.R., MATTEI, L.N., ROGERS, K.E. and ISOM, L.L. (2000). Cloning, localization, and functional expression of sodium channel b1A subunits. J. Biol. Chem. 275: 1079-1088.

KIM, D.Y., CAREY, B.W., WANG, H., INGANO, L.A., BINSHTOK, A.M., WERTZ, M.H. PETTINGELL, W.H., HE, P., LEE, V.M., WOOLF, C.J. etal., (2007). BACE1 regulates voltage-gated sodium channels and neuronal activity. Nat. Cell Biol. 9: 755-764.

KIM, D.Y., INGANO, L.A., CAREY, B.W., PETTINGELL, W.H. and KOVACS, D.M (2005). Presenilin/gamma-secretase-mediated cleavage of the voltage-gated sodium channel beta2-subunit regulates cell adhesion and migration. J. Biol. Chem. 280: 23251-23261.

LAEDERMANN, C.J., SYAM, N., PERTIN, M., DECOSTERD, I. and ABRIEL, H. (2013). beta1- and beta3- voltage-gated sodium channel subunits modulate cell surface expression and glycosylation of Nav1.7 in HEK293 cells. Front. Cell. Neurosci. 7: 137

LOPEZ-SANTIAGO, L.F., PERTIN, M., MORISOD, X., CHEN, C., HONG, S., WILEY, J., DECOSTERD, I. and ISOM, L.L. (2006). Sodium channel beta2 subunits regulate tetrodotoxin-sensitive sodium channels in small dorsal root ganglion neurons and modulate the response to pain. J. Neurosci. 26: 7984-7994.

MALHOTRA, J.D., KAZEN-GILLESPIE, K., HORTSCH, M. and ISOM, L.L. (2000) Sodium channel $\beta$ subunits mediate homophilic cell adhesion and recruit ankyrin to points of cell-cell contact. J. Biol. Chem. 275: 11383-11388.

MALHOTRA, J.D., KOOPMANN, M.C., KAZEN-GILLESPIE, K.A., FETTMAN, N., HORTSCH, M. and ISOM, L.L. (2002). Structural requirements for interaction of sodium channel b1 subunits with ankyrin. J. Biol. Chem. 277: 26681-26688.

MALHOTRA, J.D., THYAGARAJAN, V., CHEN, C. and ISOM, L.L. (2004). Tyrosinephosphorylated and nonphosphorylated sodium channel beta1 subunits are differentially localized in cardiac myocytes. J. Biol. Chem. 279: 40748-40754.

MARIONNEAU, C., CARRASQUILLO, Y., NORRIS, A.J., TOWNSEND, R.R., ISOM, L.L., LINK, A.J. and NERBONNE, J.M. (2012). The sodium channel accessory subunit Navbeta1 regulates neuronal excitability through modulation of repolarizing voltage-gated $\mathrm{K}(+)$ channels. J. Neurosci. 32: 5716-5727.

MCEWEN, D.P., CHEN, C., MEADOWS, L.S., LOPEZ-SANTIAGO, L. and ISOM, L.L. (2009). The voltage-gated $\mathrm{Na}+$ channel beta3 subunit does not mediate trans homophilic cell adhesion or associate with the cell adhesion molecule contactin. Neurosci. Lett. 462: 272-275

MCEWEN, D.P. and ISOM, L.L. (2004). Heterophilic interactions of sodium channel beta1 subunits with axonal and glial cell adhesion molecules. J. Biol. Chem. 279: 52744-52752

MEADOWS, L.S. and ISOM, L.L. (2005). Sodium channels as macromolecular 
complexes: implications for inherited arrhythmia syndromes. Cardiovasc. Res. 67: 448-458.

MORAN, O., CONTI, F. and TAMMARO, P. (2003). Sodium channel heterologous expression in mammalian cells and the role of the endogenous beta1-subunits. Neurosci. Lett. 336: 175-179.

MORGAN, K., STEVENS, E.B., SHAH, B., COX, P.J., DIXON, A.K., LEE, K., PINNOCK, R.D., HUGHES, J., RICHARDSON, P.J., MIZUGUCHI, K. et al., (2000). b3: An additional auxiliary subunit of the voltage-sensitive sodium channel that modulates channel gating with distinct kinetics. Proc. Natl. Acad. Sci. U.S.A. 97: 2308-2313.

MYCIELSKA, M.E., FRASER, S.P., SZATKOWSKI, M. and DJAMGOZ, M.B. (2003). Contribution of functional voltage-gated $\mathrm{Na}^{+}$channel expression to cell behaviors involved in the metastatic cascade in rat prostate cancer: II. Secretory membrane activity. J. Cell. Physiol. 195: 461-469.

MYCIELSKA, M.E., PALMER, C.P., BRACKENBURY, W.J. and DJAMGOZ, M.B. (2005). Expression of $\mathrm{Na}^{+}$-dependent citrate transport in a strongly metastatic human prostate cancer $\mathrm{PC}-3 \mathrm{M}$ cell line: regulation by voltage-gated $\mathrm{Na}^{+}$channel activity. J. Physiol. 563: 393-408.

NAKAJIMA, T., KUBOTA, N., TSUTSUMI, T., OGURI, A., IMUTA, H., JO, T., OONUMA H., SOMA, M., MEGURO, K., TAKANO, H. et al., (2009). Eicosapentaenoic acid inhibits voltage-gated sodium channels and invasiveness in prostate cancer cells. Br. J. Pharmacol. 156: 420-431.

NAMADURAI, S., BALASURIYA, D., RAJAPPA, R., WIEMHOFER, M., STOTT, K., KLINGAUF, J., EDWARDSON, J.M., CHIRGADZE, D.Y. and JACKSON, A.P. (2014). Crystal Structure and Molecular Imaging of the Nav Channel beta3 Subunit Indicates a Trimeric Assembly. J. Biol. Chem. 289: 10797-10811.

NELSON, M., MILLICAN-SLATER, R., FORREST, L.C. and BRACKENBURY, W.J. (2014). The sodium channel beta1 subunit mediates outgrowth of neurite-like processes on breast cancer cells and promotes tumour growth and metastasis. Int. J. Cancer 135: 2338-2351.

NELSON, M., YANG, M., DOWLE, A.A., THOMAS, J.R. and BRACKENBURY, W.J. (2015). The sodium channel-blocking antiepileptic drug phenytoin inhibits breast tumour growth and metastasis. Mol. Cancer 14: 13.

NGUYEN, H.M., MIYAZAKI, H., HOSHI, N., SMITH, B.J., NUKINA, N., GOLDIN, A.L. and CHANDY, K.G. (2012). Modulation of voltage-gated $\mathrm{K}+$ channels by the sodium channel beta1 subunit. Proc. Natl. Acad. Sci. USA 109: 18577-18582.

O'MALLEY, H.A., SHREINER, A.B., CHEN, G.-H., HUFFNAGLE, G.B. and ISOM, L.L. (2009). Loss of $\mathrm{Na}^{+}$channel 2 subunits is neuroprotective in a mouse model of multiple sclerosis. Mol. Cell. Neurosci. 40: 143-155.

OYAMA, F., MIYAZAKI, H., SAKAMOTO, N., BECQUET, C., MACHIDA, Y., KANEKO, K., UCHIKAWA, C., SUZUKI, T., KUROSAWA, M., IKEDA, T. et al., (2006). Sodium channel beta4 subunit: down-regulation and possible involvement in neuritic degeneration in Huntington's disease transgenic mice. J. Neurochem. 98: 518-529.

PATINO, G.A., BRACKENBURY, W.J., BAO, Y.Y., LOPEZ-SANTIAGO, L.F., O'MALLEY, H.A., CHEN, C.L., CALHOUN, J.D., LAFRENIERE, R.G., COSSETTE, P., ROULEAU, G.A. et al., (2011). Voltage-Gated Na+ Channel beta 1B: A Secreted Cell Adhesion Molecule Involved in Human Epilepsy. J. Neurosci. 31: 14577-14591.

PATINO, G.A. and ISOM, L.L. (2010). Electrophysiology and beyond: Multiple roles of $\mathrm{Na}(+)$ channel beta subunits in development and disease. Neurosci. Lett. 486:53-59.

PLANELLS-CASES, R., CAPRINI, M., ZHANG, J., ROCKENSTEIN, E.M., RIVERA, R.R., MURRE, C., MASLIAH, E. and MONTAL, M. (2000). Neuronal death and perinatal lethality in voltage-gated sodium channel alpha(II)-deficient mice. Biophys. J. 78: 2878-2891.

QIN, N., D'ANDREA, M.R., LUBIN, M.L., SHAFAEE, N., CODD, E.E. and CORREA A.M. (2003). Molecular cloning and functional expression of the human sodium channel beta1B subunit, a novel splicing variant of the beta1 subunit. Eur. J. Biochem. 270: 4762-4770.

QU, Y., CURTIS, R., LAWSON, D., GILBRIDE, K., GE, P., DISTEFANO, P.S., SILOSSANTIAGO, I., CATTERALL, W.A. and SCHEUER, T. (2001). Differential modulation of sodium channel gating and persistent sodium currents by the beta1, beta2, and beta3 subunits. Mol. Cell. Neurosci. 18: 570-580.

RATCLIFFE, C.F., WESTENBROEK, R.E., CURTIS, R. and CATTERALL, W.A (2001). Sodium channel beta1 and beta3 subunits associate with neurofascin through their extracellular immunoglobulin-like domain. J. Cell Biol. 154: 427-434

RICCIO, R.V. and MATTHEWS, M.A. (1985). Effects of intraocular tetrodotoxin on dendritic spines in the developing rat visual cortex: a Golgi analysis. Brain Res. 351: 173-182.

ROGER, S., BESSON, P. and LE GUENNEC, J.Y. (2003). Involvement of a nove fast inward sodium current in the invasion capacity of a breast cancer cell line. Biochim. Biophys. Acta 1616: 107-111.

SCHALLER, K.L. and CALDWELL, J.H. (2000). Developmental and regional expression of sodium channel isoform $\mathrm{NaCh} 6$ in the rat central nervous system. $J$ Comp. Neurol. 420: 84-97.

SRINIVASAN, J., SCHACHNER, M. and CATTERALL, W.A. (1998). Interaction of voltage-gated sodium channels with the extracellular matrix molecules tenascin-C and tenascin-R. Proc. Natl. Acad. Sci. USA 95: 15753-15757.

WONG, H.K., SAKURAI, T., OYAMA, F., KANEKO, K., WADA, K., MIYAZAKI, H., KUROSAWA, M., DE STROOPER, B., SAFTIG, P. and NUKINA, N. (2005). beta subunits of voltage-gated sodium channels are novel substrates of BACE1 and gamma -secretase. J. Biol. Chem. 280: 23009-23017.

XIAO, Z.C., RAGSDALE, D.S., MALHOTRA, J.D., MATTEI, L.N., BRAUN, P.E. SCHACHNER, M. and ISOM, L.L. (1999). Tenascin-R is a functional modulator of sodium channel beta subunits. J. Biol. Chem. 274: 26511-26517.

YANG, M. and BRACKENBURY, W.J. (2013). Membrane potential and cancer progression. Front. Physiol. 4: 185.

YANG, M., KOZMINSKI, D.J., WOLD, L.A., MODAK, R., CALHOUN, J.D., ISOM, L.L. and BRACKENBURY, W.J. (2012). Therapeutic potential for phenytoin: targeting $\mathrm{Na}(\mathrm{v}) 1.5$ sodium channels to reduce migration and invasion in metastatic breast cancer. Breast Cancer Res. Treat. 134: 603-615.

YEREDDI, N.R., CUSDIN, F.S., NAMADURAI, S., PACKMAN, L.C., MONIE, T.P., SLAVNY, P., CLARE, J.J., POWELL, A.J. and JACKSON, A.P. (2013). The immunoglobulin domain of the sodium channel beta3 subunit contains a surface-localized disulfide bond that is required for homophilic binding. FASEB J. 27: 568-580.

YU, F.H., MANTEGAZZA, M., WESTENBROEK, R.E., ROBBINS, C.A., KALUME, F., BURTON, K.A., SPAIN, W.J., MCKNIGHT, G.S., SCHEUER, T. and CATTERALL, W.A. (2006). Reduced sodium current in GABAergic interneurons in a mouse model of severe myoclonic epilepsy in infancy. Nat. Neurosci. 9: 1142-1149.

YU, F.H., WESTENBROEK, R.E., SILOS-SANTIAGO, I., MCCORMICK, K.A., LAWSON, D., GE, P., FERRIERA, H., LILLY, J., DISTEFANO, P.S., CATTERALL, W.A et al., (2003). Sodium channel beta4, a new disulfide-linked auxiliary subunit with similarity to beta2. J. Neurosci. 23: 7577-7585. 


\section{Further Related Reading, published previously in the Int. J. Dev. Biol.}

Visualization, characterization and modulation of calcium signaling during the development of slow muscle cells in intact zebrafish embryos

Chris Y. Cheung, Sarah E. Webb, Donald R. Love and Andrew L. Miller

Int. J. Dev. Biol. (2011) 55: 153-174

http://dx.doi.org/ijdb.103160cc

The role of ion fluxes in polarized cell growth and morphogenesis: the pollen tube as an experimental paradigm

Erwan Michard, Filipa Alves and José A. Feijó

Int. J. Dev. Biol. (2009) 53: 1609-1622

http://dx.doi.org/ijdb.072296em

Ion channels that control fertility in mammalian spermatozoa

Betsy Navarro, Yuriy Kirichok, Jean-Ju Chung and David E. Clapham

Int. J. Dev. Biol. (2008) 52: 607-613

http://dx.doi.org/ijdb.072554bn

Sperm-activating peptides in the regulation of ion fluxes, signal transduction and motility Alberto Darszon, Adán Guerrero, Blanca E. Galindo, Takuya Nishigaki and Christopher D. Wood Int. J. Dev. Biol. (2008) 52: 595-606

http://dx.doi.org/ijdb.072550ad

The choice between epidermal and neural fate: a matter of calcium.

Marc Moreau and Catherine Leclerc

Int. J. Dev. Biol. (2004) 48: 75-84

http://www.ijdb.ehu.es/web/paper/15272372

5 yr ISI Impact Factor $(2013)=2.879$
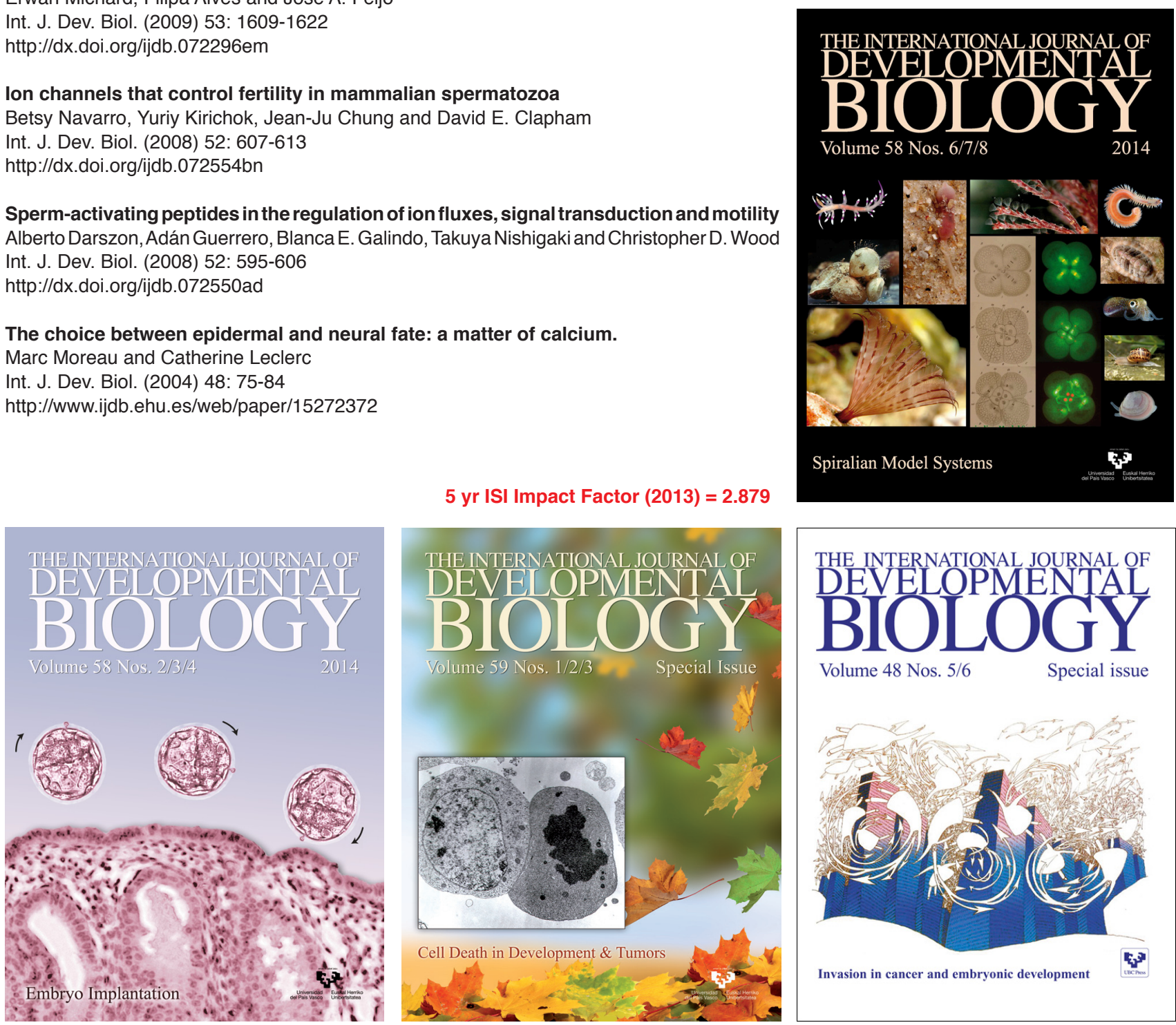

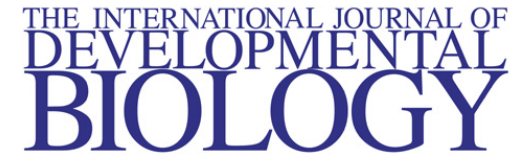

Volume 48 Nos. $5 / 6$

Special issue

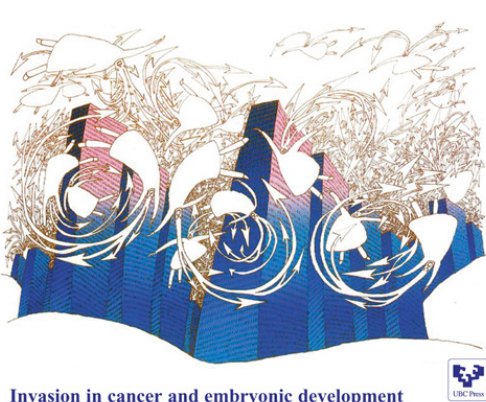

Invasion in cancer and embryonic development 